\title{
TEACHER EDUCATION IN FINLAND
}

\section{Iryna Chystiakova}

\section{INTRODUCTION}

Modernization processes in pedagogical staff training in connection with integration of Ukrainian higher education into the European Higher Education Area require new approaches to solving problems of social and professional formation, updating of theoretical views and practical actions on improvement of teachers training.

Reforms of Ukrainian education system are taking place in the context of global change and are leading to emergence of a society whose key characteristic is interaction with other countries. Interesting in this respect is Finland, which has achieved considerable success in teachers training and professional development. It was the Finnish scientists who had introduced the concept of "research-based teacher training" into international scientific circulation. Long before the Bologna Initiatives, a master's degree was introduced in Finland as a basic qualification level for primary and secondary school teachers. The success of Finnish education became apparent at the beginning of the 21st century, when, as a result of an international assessment of students' academic achievement (PISA 2001, 2003, 2006, 2009), Finnish students were found to have the highest scores, constantly ranking first in various subject areas.

Literature review on the specified issue has shown that Finland's progressive experience of teacher training has not been studied enough by Ukrainian scientists. Some aspects of Finnish education are revealed in the studies of such domestic scholars as V. Butova, I. Kozina, O. Novikova, O. Pershukova, V. Polokhalo (school education); K. Korsak, L. Liashenko, O. Shcherbak (vocational education in Finland); V. Luhovyi, Zh. Talanova (training of scientific personnel); N. Baseliuk, K. Kotun, S. Prokhorova (teacher training). The importance of the problem and its socio-pedagogical significance actualize the issue of scientific search in this direction.

\section{Historical context of teacher training in Finland}

In the context of considering the issue of historical development of teacher education and training in Finland, we'd like to note that it has two traditional directions of development. The first and the longest direction is training teachers for secondary education, and the second is training teachers for primary schools. In addition, the second direction is closely connected 
with preschool teachers training. Nowadays, teacher education in Finland is a multifaceted industry, involving a diverse group of teachers, including those working in preschool, vocational and adult education.

In order to clarify the historical context of teacher education in Finland, we consider it necessary to refer to its origins. Thus, the first education institution in which future teachers were trained was seminarium pedagogicum. Such seminaria did not last long. The lectures delivered in these institutions to future teachers were non-systematic and depended on the interests of professors ${ }^{1}$. However, it should be emphasized that they had a significant impact on the teacher training process in the country.

A significant event in Finnish teacher education development was creation in 1852 of the first professorial Chair in Education, since the Professor in education also had to deliver lectures on teaching methods, to form students' teaching skills of a certain subject. Future subject teachers for the secondary school studied selected subjects at subject faculties and went on teaching practice to a training school, which was located at the university ${ }^{2}$.

It should be noted that pedagogy was considered an auxiliary subject, and therefore its status was different from other subjects. However, Finnish scientist $\mathrm{T}$. Iisalo emphasizes the significant influence of teacher education on solving practical issues concerning the role of the professor, which was a unique phenomenon in Europe at that time ${ }^{3}$.

An important step in Finnish teacher education development was founding of the first teacher training college for primary school teachers in Jyväskylä in 1863. Its curriculum was designed according to Swiss and German models. Therefore, the influence of the pedagogical views of J.J. Rousseau, J. H. Pestalozzi and F. A. W. Diesterweg. A characteristic feature of the College of Education was close links between theory and practice of education. On the basis of the Jyväskylä College model many teacher training colleges have been established.

The analysis of legislative, regulatory documents and scientific literature has made it possible to distinguish two stages of teacher education development in Finland:

\footnotetext{
${ }^{1}$ Hansen, S.-E., Wenestam, C.-G. (1999). On central dimensions of teacher education - a Finnish perspective. TNTEE Publications, Vol. 2, N 1, 117-125.

2 Kansanen, P. (2003). Teacher Education in Finland: Current Models and New Developments. In Bob Moon, Lazar Vlasceanu and Leland Conley Barrows (Eds.), Institutional approaches to teacher education within higher education in Europe: Current models and new developments. Bucharest: Unesco - Cepes, pp. 85-108.

${ }^{3}$ Iisalo, T. (1979). The Science of Education in Finland: 1828-1918. Helsinki: Societas Scientiarum Fennica.
} 
1) reformatory (70-90's of the twentieth century);

2) modernization (1999 - till present).

Below we'll describe each of the identified stages.

The first stage is characterized by creation of a legal framework for teacher education in Finland. After many intermediate stages in the development of teacher education in Finland, the Teacher Education Act $844 / 1971$ was adopted in 1971. In 1974, all teacher training for primary and secondary schools was transferred to universities.

At the same time, faculties of education were established at each university, with departments of education and teacher training. The staff of the education department carried out research in the field of general education and worked on the problems of management and planning of education. Teachers training departments are structural divisions of universities whose activities cover both teacher education and research in teaching and pedagogical education ${ }^{4}$.

At this stage, the Teacher Training Committee of the Ministry of Education of Finland, which acted as the expert body of the State Council for preparation of socially important reforms and changes, played a significant role in the development of teacher education. The Committee identified the key ideas of reforming teacher education:

- "universitization" of teacher education through transfer of primary school teachers to universities with the aim of increasing the academic level of teacher education, enhancing interaction between education and research, introducing specific standards for training secondary school teachers;

- standardization of teacher education in order to achieve continuity and complementarity in teacher education programs;

- new assessment of the place of pedagogical sciences in teacher training, which is manifested in the increase of requirements for teacher training, in the integration of theoretical and practical teacher training in order to form a teacher-researcher, in the integration of pedagogical and special (subject) teacher training;

- increasing the focus of teacher education on solving social problems in order to prepare a teacher for realization of active public position and public responsibilities;

4 Kansanen, P. (2003). Teacher Education in Finland: Current Models and New Developments. In Bob Moon, Lazar Vlasceanu and Leland Conley Barrows (Eds.), Institutional approaches to teacher education within higher education in Europe: Current models and new developments. Bucharest: Unesco - Cepes, pp. 85-108. 
- increasing quantitative and qualitative indicators of a holistic system of teacher education, including postgraduate education ${ }^{5}$.

Important for teacher education development in Finland had become the report of the Committee of 1975, which emphasized that:

- teacher education should be academic and carried out at universities;

- uniform for different categories of teachers;

- basic education of future teachers should give a general and broad qualification to all teachers, and on this common basis, in-service training may be improved;

- pedagogical block should be designed in such a way that enable teachers not only to fulfill their professional responsibilities but also to promote social and emotional growth of their students. Teachers should be optimistic about their work. More integration require theoretical and practical classes as well as subject and pedagogical research;

- teacher education must include social and educational policy studies ${ }^{6}$.

Therefore, we can conclude that the main idea of this document is that teacher education should prepare a specialist with a science-based approach to work.

Following further reform in 1979, the minimum qualification required for both primary and secondary school teachers was defined as a master's degree, requiring approximately five years of careful academic and practical work. This served three main purposes:

1) it combined primary and secondary education, giving them both a "common core" (thus, not only simplifying learning but also making it possible to "transfer" teachers from one stream to another;

2) teachers, even at the elementary level, had to meet high academic standards (and benefit from "academic equality");

3) teachers of upper secondary schools were also required to conduct pedagogical research ${ }^{7}$.

90s of the twentieth century in the history of Finnish teacher education are characterized by a change in the vectors of the educational policy development, which can be expressed in terms of "achievement of perfection", "realization of hidden resources", "development of quality". The most significant changes are the following:

5 Teacher education in Finland: Present and future trends and challenges (Studia Paedagogic 11) (1996). Seppo Tella (ed.). Helsinki, Vantaa: University of Helsinki.

${ }^{6}$ Niemi, H., Jakku-Sihvonen, R. (2006). Research-based Teacher Education. In Hannele Niemi and Ritva Jakku-Sihvonen (Eds), Research-based Teacher Education in Finland Reflections by Finnish Teacher Educators. Turku: Finnish Educational Research Association, pp. 31-50.

${ }^{7}$ Ibid. 
- new understanding of the essence, process and forms of learning and teaching is developing;

- students are given more opportunities for personal learning paths at universities (choice of programs, terms, rates of study, etc.);

- role of the teacher changes;

- in the context of decentralized education management, the range of powers and opportunities of future and working teachers is expanded ${ }^{8}$.

In the 90s, academic degrees in almost all disciplines continued to be reformed in Finland. A new regulation in the education sector (1995) brought the following levels of degrees to the faculties of education:

- Bachelor of Education (120 credits);

- Master of Education (160 credits);

- Doctor of Education (next 160 credits).

In order to promote student mobility at national and international levels, a bachelor's degree of 120 credits is being introduced, which is new for Finland. However, the basic qualification of the teacher remains a master's degree with writing and defending a master's thesis.

The second stage. The next major change in teacher education was the result of the Bologna Process, according to which, with support of the Ministry of Education of Finland, all universities, responsible for teacher education, united into a single national network (Vokke project, 2005) and began jointly preparing new curricula for teacher education.

At this stage, the key concepts in teacher training in Finland have become "experiment-based learning" and "research-based education", and the main problem - introducing research into teacher education.

In our view, important at the beginning of the 21 st century is the fact that Finnish teacher education reform has reached a consensus on the key idea: teacher education should equip a future teacher with research-based knowledge, skills and methods of teaching, collaboration at school, interaction with parents and other stakeholders.

The contents of this stage will be discussed in more detail below.

\section{Regulatory and procedural foundations of teacher education in Finland}

Teacher training in Finland is carried out at eight universities (University of Helsinki, University of Eastern Finland, University of Jyväskylä, University of Lapland, University of Oulu, University of Tampere, University of Turku, Åbo Akademi University) at the faculties of education,

8 Teacher education in Finland: Present and future trends and challenges (Studia Paedagogic 11) (1996). Seppo Tella (ed.). Helsinki, Vantaa: University of Helsinki. 
faculties of teacher training, teacher training schools, where students go on teaching practice, as well as polytechnics engaged in training teachers vocational education field.

The main approach in teacher training Finnish researchers H. Niemi, A. Mikkola， P. Kansanen, R. Rinne, A. Toom, L. Krokfors, K. Maaranen consider research-based one.

Preparation of Finnish teachers in the 21 st century is based on the following legislative documents:

- Basic Education Act (1998)

- Basic Education Statute (1998) ${ }^{10}$;

- Teacher Education Act $(1971)^{11}$;

- Teacher Education Statute (1986) ${ }^{12}$;

- Statute on Educational Degrees and Teacher Education (1995) ${ }^{13}$;

- Agreement on Wages and Conditions of Employment in the Municipal Educational Sector $(1998)^{14}$;

- Framework Curriculum for the Comprehensive School (1994) ${ }^{15}$;

- The Guidelines for Pupil Evaluation during Basic Education (1999) ${ }^{16}$;

- The Criteria for Graduating Evaluation in the Basic Education $(1999)^{17}$.

Teacher Education Act and Teacher Education Statute (L 1971, S 1986) (the Act consists of nine sections and the Statute of seven) state that teacher education for primary and secondary schools is organized at the faculties of education at eight universities. The Statute states that further rules are

${ }^{9}$ L 1998. Perusopetuslaki 21.8.1998/628 (The Basic Education Act), in H. Ranta (ed)). Opetustoimen lainsäädäntö 1999. Helsinki: Kauppakaari OYJ, 1998, pp. 1-8.

${ }^{10}$ S 1998. Perusopetusasetus 20.11.1998/852 (The Basic Education Statute), in H. Ranta (ed)).

${ }^{11}$ L 1971. Opettajankoulutuslaki 10.12.1971/844 (Teacher Eduction Act). In H. Ranta (Ed)). Opetustoimen lainsäädantö 1999. Helsinki: Kauppakaari OYJ, 1998, p. 22.

${ }^{12}$ S 1986. Opettajankoulutusasetus 13.6.1986/486 (Teacher Education Statute). In H. Ranta (ed.) Opetustoimen lainsäädantö 1999. Helsinki: Kauppakaari OYJ, 1998, pp. 22-23.

13 S 1995. Asetus kasvatustieteellisen alan tutkinnoista ja opettajankoulutuksesta 21.4.1995/576 (Statute on Educational Degrees and Teacher Education). In H. Ranta (ed.) Opetustoimen lainsäädantö 1999. Helsinki: Kauppakaari OYJ, 1998, pp. 32-36.

${ }^{14}$ A 1998. Kunnallinen opetusalan virka- ja työehtosopimus 1998-1999 (Agreement on Wages and Conditions of Employment in Municipal Educational Sector). Helsinki: Kunnallinen työmarkkinalaitos, 1998.

${ }^{15}$ CUR 1994. Framework Curriculum for the Comprehensive School 1994. National Board of Education. Helsinki: Painatuskeskus. [An official version translated in English]

${ }^{16}$ CUR 1999a. Perusopetuksen oppilaanarvioinnin perusteet 1999. (The Guidelines for Student Evaluation in the Basic Education 1999). Opetushallitus.

17 CUR 1999b. Perusopetuksen päättöarvioinnin kriteerit. Arvosanan hyvä (8) kriteerit yhteisissä oppiaineissa. (The Criterions for Graduating Evaluation in the Basic Education. The criterions of the mark "good" (8) in the common teaching subjects). Opetushallitus. 
proposed by the Ministry of Education (1986, § 24). Thus, teacher education in Finland is organized in the same way as higher education in general.

The main legal framework for the content of teacher education is laid down in the Statute on Educational Degrees and Teacher Education (S 1995). One section of the statute is devoted to teacher education, in addition to information on the general master's degree in education, which is the basis of all teacher education for the comprehensive school. Training of classroom teachers and subject teachers for a comprehensive school lasts 4 years or 160 academic weeks. It is envisaged that the specific purpose of teacher education in relation to general, academic education, is to instill "willingness to act independently as a teacher, guide and educator". Determining the level of education of a kindergarten teacher and teacher of a bachelor level (120 weeks) is also included in this law (S 1995, § 10).

The master's degree of classroom teachers includes:

1) "Educational Science Disciplines" as a core subject, which includes Education, Adult Education, Special Education, Educational Psychology, Sociology of Education, Music Education, Home Economics, and, as a whole, Craft Education, Craft Science, Textile Work;

2) Pedagogical Studies;

3) Multi-Subject Studies in General Education (S 1995, § 12).

Pedagogical research is hereinafter defined as "subjects that are didactically oriented and include pedagogical practice" (S 1995, § 16). It should be noted that the Statute does not define any minor subjects for the formation of competences of primary school teachers. Universities have traditional academic freedom to determine content of their disciplines.

The master's degree of a subject teacher includes, first, study of one or two academic subjects and, second, pedagogical research. "The study of the subject of instruction implies classes that will help to master content of the subject necessary for teacher's work" (S 1995, § 13). The Statute states that pedagogical studies are also available separately, which continues tradition of separate pedagogical studies for subject teachers (S 1995, § 12).

It should be emphasized that in Finnish legislation on education there are practically no direct references to both the teacher's tasks (i.e. what teachers should do) and their qualifications (i.e. what teachers should know or be able to do). There are only a few provisions in which the teacher is only mentioned. In the text of the law, the teacher is mentioned only under the heading "Employees", which states that the "organizer of education" (i.e. municipality) "must have enough teachers' offices or teachers with full employment contracts. In addition, the organizer may have part-time teachers, school assistants and other staff "(L 1998, § 37). The Statute has a reference to the teacher. First, it states that teaching in a secondary school is carried out by classroom teachers, subject teachers, educational consultants 
and special teachers (S 1999, § 1). Second, it identifies those who are to carry out the student assessment ( $\$ 13$ and $\S 19)$. Third, it establishes procedures for maintaining discipline in the classroom $(\S 17)$.

Thus, it can be concluded that there are no direct statements in the legislative texts confirming the teacher's tasks. Traditionally, a teacher is directly present in the legislative texts only as an employee of the school, as an assessor and as a carrier of the discipline.

An interesting detail in Finnish legislation on education is that very little is said about how a teacher works or continues to study. All the rules provided in the Statute on Qualifications of the Staff in Education $(1998)^{18}$, concern only basic training. The Teacher Education Act of the early 1970s stated that "teacher education means both basic teacher education and additional education", and that "the purpose of additional education is to empower the teacher in charge of education" $(1971, \S 1)$. According to later legislation, universities, their faculties of education or faculties of teacher training responsible for basic teacher education have responsibilities mentioned in the legislation only in "advanced scientific studies", that is, in postgraduate studies for the degree of Licentiate and $\mathrm{PhD}$ in Education. There is no reference to further, advanced, continuous teacher training (S 1995, § 3 and $\S 8$ ). In Finland, there is an institute (Opetusalan koulutuskeskus), which organizes "additional training for teachers and other teaching staff". It is controlled by the NBE and Laws 1259/1997 and $187 / 1998$, but there is no reference in the legislative documents to any obligation on teachers to use its services.

Turning to procedural characteristics of teacher education in Finland we'd like to mention that most students who are obtaining teacher education study at the universities.

The first stage in a student's teaching career is a bachelor's degree, which includes 180 ECTS credits. The second is a master's degree, which is worth 120 ECTS credits. Only specialists with master's degree are allowed to teach in schools. Obtaining this degree requires completion of such courses as:

- communication competence (12 credits);

- education technology (75 credits);

- pedagogy and psychology (35 credits);

- basic subject specialization (35 credits);

- additional subject specialization (35 credits);

- optional courses (5-8 credits).

${ }^{18}$ S 1998. Asetus opetustoiminnan henkilöstön kelpoisuusvaatimuksista 986/14.12.1998 (Statute on Qualifications of the Staff in Education). 
Students take basic courses, intermediate advanced level courses in a profile specialty, totaling 120 ECTS credits, and basic and intermediate courses in an additional specialty - 60 ECTS credits. The full degree, with a total of 300 ECTS credits, is obtained in five years.

Students pursuing a career as a kindergarten teacher or adult evening school teacher complete a 3-year undergraduate program. Although this qualification is enough for both kindergarten and evening school, many teachers continue their studies to obtain a master's degree.

Teacher education consists of disciplines that combine teaching of a specialized subject for a subject teacher and teaching practice. Students' teaching practice can take place both in schools of vocational training at teacher training departments, and in traditional schools.

Kindergarten trainees usually practice at day care centers. Teachers with a master's degree can continue their studies at doctoral level.

As it has been noted above, teacher training in Finland is organized by universities and vocational higher education institutions. Pre-school teachers receive a $\mathrm{BEd}$, which includes 180 credits (ETCS). This degree gives the right to be a kindergarten teacher and a preschool teacher. Classroom teachers receive MEd (ETCS 300 credits). This degree gives the right to work as a classroom teacher and a preschool teacher.

Subject teachers receive a master's degree (300 ETCS credits). There are two options for obtaining qualification of a particular subject teacher. The most common way is to start studying the subject first at university and then through pedagogical research. After these pedagogical studies, everyone has the right to teach the relevant subject. Another option is to go directly to the subject teacher training. This direct selection for teacher education is becoming more widespread, but so far it is only possible in a few subjects.

Special-education teachers receive a master's degree in pedagogical sciences (ETCS 300 credits). This degree gives the right to be a specialeducation teacher in general schools and a classroom teacher.

Vocational school teachers usually receive a university or a vocational school diploma, then work for several years, and thereafter conduct pedagogical research at a vocational school in order to get qualification of a teacher.

The competition for the teaching faculties of universities is currently 1015 applicants for the position, which is one of the highest in the world. The entrance examinations are conducted in two stages:

1) at the first stage results of the school exams are taken into account;

2) the second stage is intended to test entrants' knowledge in a specific subject area, as well as their social interaction skills and motivation. 
During their studies, the students constantly analyze pedagogical situations offered by the teachers and repeatedly go through a variety of interviews, simultaneously studying a wide range of pedagogical disciplines.

\section{Content foundations of teacher education in Finland}

In order to clarify content foundations of teacher education in Finland, we consider it necessary, first of all, to focus on the basic principles that underpin development of the curriculum for teachers. Such principles include $^{19}$ :

1. Autonomy, responsibility and trust. At the heart of Finnish teacher education is the belief that teachers - at all levels - not only can, but must be transformed into autonomous professionals - experts in their fields, capable of solving various tasks (pedagogical, administrative, family- or communityrelated, even relationships with local businesses) on their own or in collaboration with their colleagues and local community.

Developing these qualities as a teacher, on the one hand, makes teaching one of Finland's most sought after and prestigious professions; and, on the other hand, forms the basis of trust.

As P. Sahlberg points out, "Teachers and school principals play a key role in curriculum development. Teacher education gives them knowledge and well-developed planning skills. In addition, the importance of curriculum development in teacher practice has helped to shift the emphasis of professional development from fragmented learning to a more systematic, theoretically substantiated efforts to improve school levels"20.

2. Science-based approach. It is important to highlight two main goals behind this principle. First, this approach allows students-teachers to stay upto-date with the latest research in their field, as well as to introduce new knowledge. But the second, more important goal is also to develop teachers able to reflect on their own beliefs and practices. "The goal of researchbased teacher education for future subject teachers", notes P. Kansanen, "is engaging in reflective learning that will help new teachers address problems they may face in practice through autonomous thinking and logical reasoning" 21 .

${ }^{19}$ Teacher education in Finland. Режим доступу: http://www.theeducationist.info/teachereducation-in-finland/

${ }^{20}$ Sahlberg, P. (2010). The Secret to Finland Success: Educating Teachers. Stanford Centre for Opportunity in Education.

${ }_{21}$ Kansanen, P. (2003). Teacher Education in Finland: Current Models and New Developments. In Bob Moon, Lazar Vlasceanu and Leland Conley Barrows (Eds.), Institutional approaches to teacher education within higher education in Europe: Current models and new developments. Bucharest: Unesco - Cepes, pp. 85-108. 
3. Emphasis on integration of theory and practice. This principle envisages allowing students-teachers to begin hands-on learning as early as possible; and at the same time emphasize interaction between practice and theory of education throughout the study period - in each academic year (from 1 to 5) and during each academic period.

"Curriculum, as noted by P. Kansanen, is regarded as a spiral (with basic courses, vertically integrated into teaching and with constant interaction of theoretical and practical aspects, supported by knowledge of research methods and content" 22 .

Vocational training for primary school teachers (grades 1-6) takes place at universities at the faculties of education and includes 120 and 160 credits for the bachelor's and master's programs respectively ${ }^{23}$. The main subjects are pedagogy, primary school subjects and teaching methods, as well as specialized education courses in counseling. The core of the program consists of both basic and additional disciplines. Mother tongue (Finnish or Swedish) and mathematics are required for all students. Arts, crafts, music and physical education are grouped into compulsory electives. The program also includes the so-called introductory disciplines, namely history, natural sciences, biology, geography, religion and ethics. Regarding additional and non-core subjects, students are offered two options: they can choose two subjects or modules, each with 15 credits, or choose one module in 35 credits. The student has the right to choose additional subjects from the courses of pedagogical or any other faculty. Although 160 credits are required to earn a master's degree, most students receive much more through additional disciplines. All subjects must be included in the teacher's certificate $^{24}$.

The subject teacher training program is designed for $4-5$ years of study. In the second year of study, students should decide whether they want to engage in teaching activities. Those who decide to become teachers begin to study pedagogy from the third year. Those students who decide to become teachers after obtaining a master's degree in another specialty may receive a teacher's certificate at the faculty of education.

Based on the analysis of the curriculum for subject and classroom teachers training, we have concluded that the level of education of the subject and classroom teachers is almost identical. The difference is only in

${ }^{22}$ Ibid.

23 Kansanen, P. (2003). Teacher Education in Finland: Current Models and New Developments. In Bob Moon, Lazar Vlasceanu and Leland Conley Barrows (Eds.), Institutional approaches to teacher education within higher education in Europe: Current models and new developments. Bucharest: Unesco - Cepes, pp. 85-108.

${ }^{24}$ Ibid. 
the main subjects of study. Future classrom teachers study pedagogy and pedagogical psychology, while future subject teachers - the subject they will teach their students. The main subject is worth 55 credits. In addition, future teachers will also receive additional 35 credits, which they can use to study one additional subject. Many students choose a third subject ${ }^{25}$. Typically, the subject teacher qualification corresponds to 180 credits. Most educators are specialized in two or more disciplines. Their number depends on the type of teaching specialty and the level of teacher training. As for the exam, it depends on the specifics of the discipline. Typically, the exam program includes questions about the psychological and social foundations of teaching, the foundations of defectology education, philosophical and historical foundations of education, interaction skills, and didactics of adult learning. The study of subject didactics takes place through lectures and in line with pedagogical practice. The main topics include planning a course for the student to teach at school, studying international trends in the development of specific subject-matter didactics, and cross-curricular relationships. The methodology of scientific and pedagogical research is studied by future educators in order to prepare students for designing scientific projects in the field of subject activity. Special attention is paid to acquaintance with professional journals and scientific reports.

We consider it necessary to emphasize that a special place is occupied by pedagogical practice. Future teachers attend basic university schools directly from the beginning of the educational process and gradually become acquainted with peculiarities of pedagogical activity at the junior level of the comprehensive school. After that, first general, then field and final teaching practice is organized. During general practice students get acquainted with peculiarities of teaching a variety of school subjects, forms of teaching, methods of students' control and assessment. They learn to plan, conduct and evaluate a variety of activities. In parallel with practice, each student creates a portfolio and also regularly participates in learning discussions that take place after each student's lesson. Quite often, field and teaching practice are combined into one system where the student has the opportunity to expand his/her own views on the teaching profession and learn about different teaching methods and techniques. The main purpose of this practice is to help the student find his/her way and teaching style. Students work in one class together with the head teacher and are responsible for a particular class over a long period.

25 Kansanen, P. (2003). Teacher Education in Finland: Current Models and New Developments. In Bob Moon, Lazar Vlasceanu and Leland Conley Barrows (Eds.), Institutional approaches to teacher education within higher education in Europe: Current models and new developments. Bucharest: Unesco - Cepes, pp. 85-108. 
Despite the differences in their role (as well as in teaching), curricula for teachers of both categories can be divided into the following broad groups ${ }^{26}$ :

1) academic disciplines;

2) scientific research;

3) pedagogical research;

4) study of communication, language and ICT;

5) personal curriculum;

6) optional studies.

\section{CONCLUSIONS}

This study explains organizational and pedagogical foundations of teacher education in Finland. As a result, we have come to the following conclusions.

1. A chronological analysis of teacher education of Finland revealed its historical origins. It has been found out that pedagogical education in the country began in the eighteenth century, when preparation of future teachers took place in seminarium pedagogicum. In the nineteenth century the first professorial Chair of Education at the University of Helsinki and the first teacher training college for primary school teachers in Jyväskylä (1863) were opened. Within chronological framework of the study the following stages of teacher education in Finland related to educational reforms of the late twentieth centure are highlighted: 1) reformatory - driven by the needs of intensification of educational reforms of 1970-1990; 2) modernization aimed at comprehensive implementation of the Bologna provisions.

2 . The normative and procedural foundations of pedagogical education in Finland are outlined. For this purpose, the documents of Finnish educational reforms (Basic Education Act, Basic Education Statute, Teacher Education Act, Teacher Education Statute, Statute on Educational Degrees and Teacher Education, Agreement on Wages and Conditions of Employment in the Municipal Educational Sector, Framework Curriculum for the Comprehensive School, The Guidelines for Pupil Evaluation during Basic Education, The Criteria for Graduating Evaluation in the Basic Education) and the structural features of teacher education have been characterized.

It is stated that the main legislative framework for the content of teacher education is laid down in the Statute on Educational Degrees and Teacher Education. Finnish educational legislation gives little information on how a teacher works or continues to study. All the rules in the Statute on Qualifications of the Staff in Education concern only basic training.

${ }^{26}$ Niemi, H. \& Jakku-Sihvonen, R. (2006). Research-based Teacher Education in Finland. Turku: Finnish Educational Research Association, pp. 31-51. 
It is found out that the first stage in a teaching career for a student is a bachelor's degree and the second is a master's degree. Only graduates with a master's degree are allowed to teach in schools.

Therefore, modern Finnish teacher education system is a complex structure that includes not only traditional university education but also various centers, vocational educational establishments and adult education system.

3. It has been established that the teacher training system in Finland is characterized by variability in the content of education, flexibility of the structure and technology of teaching, as well as the students' ability to adequately design their own career path, based on their own interests and experience. However, there is no single and universal direction of training for all teaching staff. The system offers a variety of techniques that help the future teacher find himself or herself as an educator, develop professional qualities, and find their own teaching style. Accordingly, the main goal of the Finnish education system is to train a teacher who is capable of selfdevelopment and creation of his/her own scientific and professional path.

The study does not exhaust all the aspects of the outlined problem. The issue of adult teacher training requires further investigation.

\section{SUMMARY}

This section reveals organizational and pedagogical foundations of teacher education in Finland. Historical prerequisites of teacher education are defined. The stages of teacher education in Finland, related to the educational reforms of the late twentieth (reformatory, modernization), are highlighted. Regulatory and procedural foundations of teacher education in Finland are outlined. It is stated that the main legislative framework for the content of teacher education is laid down in the Statute on Educational Degrees and Teacher Education. It has been found out that modern Finnish system of teacher education is a complex structure that includes not only traditional university training but also various centers, vocational education institutions and adult education system. The content foundations of teacher education in Finland are described. It has been established that the teacher training system in Finland is characterized by variability in the content of education, flexibility of the structure and technology of teaching, as well as the students' ability to adequately design their own career path based on their own interests and experience. It is determined that the main purpose of the Finnish education system is to train a teacher who is capable of selfdevelopment and creation of his/her own scientific and professional path. 


\section{REFERENCES}

1. A 1998. Kunnallinen opetusalan virka- ja työehtosopimus 1998-1999 (Agreement on Wages and Conditions of Employment in Municipal Educational Sector). Helsinki: Kunnallinen työmarkkinalaitos, 1998.

2. CUR 1994. Framework Curriculum for the Comprehensive School 1994. National Board of Education. Helsinki: Painatuskeskus [An official version translated in English].

3. CUR 1999a. Perusopetuksen oppilaanarvioinnin perusteet 1999. (The Guidelines for Student Evaluation in the Basic Education 1999). Opetushallitus.

4. CUR 1999b. Perusopetuksen päättöarvioinnin kriteerit. Arvosanan hyvä (8) kriteerit yhteisissä oppiaineissa. (The Criterions for Graduating Evaluation in the Basic Education. The criterions of the mark "good" (8) in the common teaching subjects). Opetushallitus.

5. Hansen, S.-E., Wenestam, C.-G. (1999). On central dimensions of teacher education - a Finnish perspective. TNTEE Publications, Vol. 2, N 1, 117-125.

6. Iisalo, T. (1979). The Science of Education in Finland: 1828-1918. Helsinki: Societas Scientiarum Fennica.

7. Kansanen, P. (2003). Teacher Education in Finland: Current Models and New Developments. Institutional approaches to teacher education within higher education in Europe: Current models and new developments I Bob Moon, Lazar Vlasceanu and Leland Conley Barrows (Eds.). Bucharest: Unesco - Cepes, pp. 85-108.

8. L 1971. Opettajankoulutuslaki 10.12.1971/844 (Teacher Eduction Act). In H. Ranta (Ed), Opetustoimen lainsäädantö 1999. Helsinki: Kauppakaari OYJ, 1998, p. 22.

9. L 1998. Perusopetuslaki 21.8.1998/628 (The Basic Education Act), in H. Ranta (ed). Opetustoimen lainsäädäntö 1999. Helsinki: Kauppakaari OYJ, 1998, pp. 1-8.

10. Niemi, H. \& Jakku-Sihvonen, R. (2006). Research-based Teacher Education in Finland. Turku: Finnish Educational Research Association, 31-51.

11.S 1986. Opettajankoulutusasetus 13.6.1986/486 (Teacher Education Statute). In H. Ranta (ed.) Opetustoimen lainsäädantö 1999. Helsinki: Kauppakaari OYJ, 1998, pp. 22-23.

12.S 1995. Asetus kasvatustieteellisen alan tutkinnoista ja opettajankoulutuksesta 21.4.1995/576 (Statute on Educational Degrees and Teacher Education). In H. Ranta (ed.) Opetustoimen lainsäädantö 1999. Helsinki: Kauppakaari OYJ, 1998, pp. 32-36.

13. S 1998. Asetus opetustoiminnan henkilöstön kelpoisuusvaatimuksista 986/14.12.1998 (Statute on Qualifications of the Staff in Education). 
14.S 1998. Perusopetusasetus 20.11.1998/852 (The Basic Education Statute), in H. Ranta (ed).

15. Sahlberg, P. (2010). The Secret to Finland Success: Educating Teachers. Stanford Centre for Opportunity in Education.

16.Teacher education in Finland. Режим доступу: http://www.theeducationist.info/teacher-education-in-finland/.

17. Teacher education in Finland: Present and future trends and challenges (Studia Paedagogic 11) (1996). Seppo Tella (ed.). Helsinki, Vantaa: University of Helsinki.

\section{Information about the author:}

Iryna Chystiakova,

Candidate of Pedagogical Sciences, Associate Professor, Associate Professor of the Chair of Pedagogy

Sumy State Pedagogical University named after A. S. Makarenko

87, Romenska str., 40002, Sumy, Ukraine ORCID ID: orcid.org/0000-0001-8645-510X 